Volume 13, Issue 1 (Winter 2021)

\title{
Potter's Bull: An Heirloom and a Gift
}

\author{
Frans Grijzenhout
}

f.grijzenhout@uva.nl

Recommended Citation:

Frans Grijzenhout, "Potter's Bull: An Heirloom and a Gift," Journal of Historians of Netherlandish Art 13:1 (Winter 2021) DOI: 10.5092/jhna.2021.13.1.2.

Available at https://jhna.org/articles/potters-bull-an-heirloom-and-a-gift/

Published by Historians of Netherlandish Art: https://hnanews.org/

Republication Guidelines: https://jhna.org/republication-guidelines/

Notes: This PDF is provided for reference purposes only and may not contain all the functionality or features of the original, online publication. This PDF provides paragraph numbers as well as page numbers for citation purposes.

ISSN: 1949-9833 


\title{
Potter's Bull: An Heirloom and a Gift
}

\author{
Frans Grijzenhout
}

Contrary to what we thought we knew about the provenance of Paulus Potter's iconic The Bull (1647; Mauritshuis, The Hague), the painting served as a gift to Prince William IV of Orange in 1749, after a stay of many decades within the family of Barbara Schas and Willem Fabricius in Haarlem. The painting may have been produced, or adapted, as a giant piece of decoration for a private house in The Hague.

Paulus Potter's The Bull, long in the collection of the Royal Picture Gallery at the Mauritshuis in The Hague, has become one of the iconic images of seventeenth-century Dutch painting (fig. 1). ${ }^{1}$ Praised in the first catalogue of the collection of paintings owned by stadholder William V of Orange in 1770, it became one of the attractions of the French national museum in the former Louvre palace in Paris, after revolutionaries seized the princely collection in The Hague in $1795 .^{2}$ In France, it was considered the epitome of Dutch realism, with its combination of humble subject matter and highly finished naturalism. Although the painting's reputation suffered in the nineteenth century under the criticism of Eugène Fromentin and others, appreciation for the work of Paulus Potter in general, and this painting in particular, saw a remarkable comeback in the twentieth century. Despite his very short period of artistic production-born in 1625, the painter died in 1654-Potter is now viewed as one of the most important animal and landscape painters of the Dutch seventeenth century. He is highly praised for the tone, light and atmosphere in his works. The fairly recent observation that the anatomy of his famous Bull may be more of a composite than a completely true "portrait" of an existing animal has done little to diminish the painting's popularity with the general public. ${ }^{3}$ 


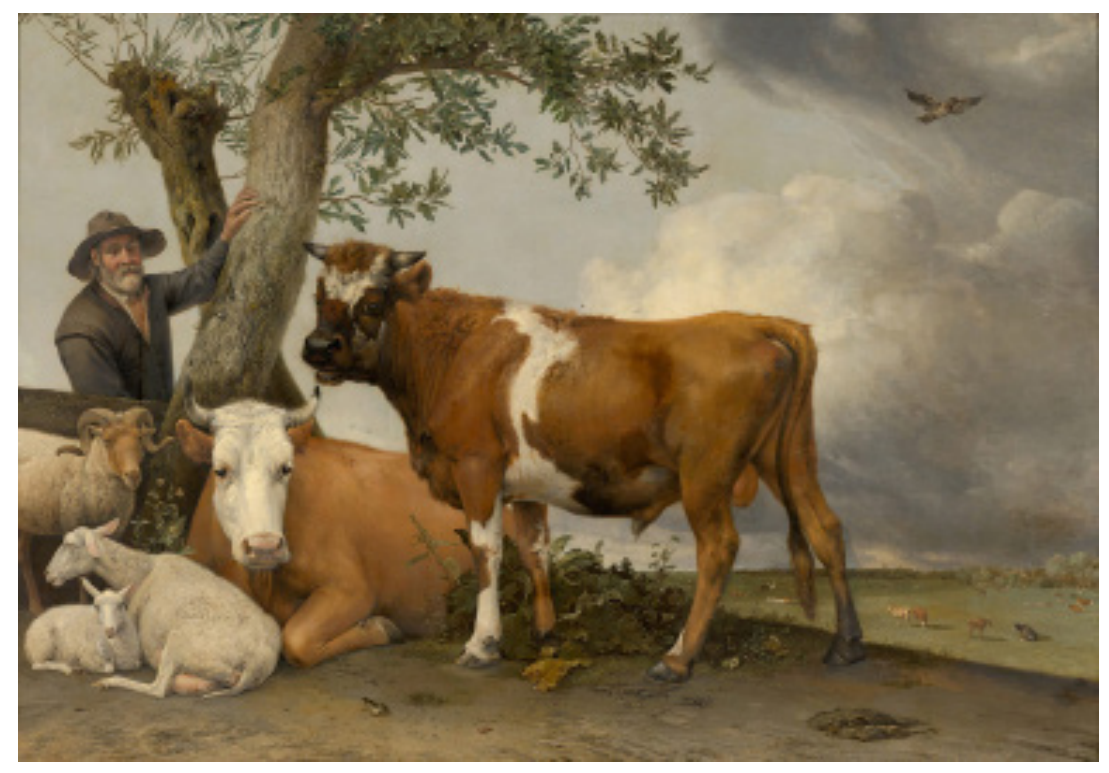

Fig. 1 Paulus Potter, The Bull, oil on canvas, 236 x $339 \mathrm{~cm}$, Mauritshuis, The Hague, inv. 136 (artwork in the public domain)

Although the painting is fully signed and dated 1647 on the fence at the left side of the work, we know very little about the circumstances under which the Bull was created. Careful visual analysis of the painting and X-ray photography have brought to light that the original canvas of the painting must have been much smaller, and that it was enlarged by the painter himself on all four sides in order to reach its present size. Thus, it seems that Potter conceived the painting first as a mere picture of a bull. Later on in the production process, he must have changed his mind, or followed the wish of an unknown patron, in order to include the animal within a larger group of cattle, herded by a man, and to place it in a wider landscape, obviously somewhere between The Hague and the nearby village of Rijswijk, identifiable by the steeple of its church on the horizon. ${ }^{4}$ We do not know the reason why Potter expanded the painting, but given the adjustments to its size and the resulting enormous scale of the work $(236 \times 339 \mathrm{~cm})$, it is hardly conceivable that it was produced for the free market. The painting's definite form seems to suggest that it was meant to be included in some kind of interior decoration and had to fit a designated place. This is, however, merely conjecture, since very little is known about the work's provenance, let alone its initial whereabouts. Nevertheless, some new information on the provenance is presented here.

\section{Potter's Bull: A Gift, in Expectation of a Return}

3 The earliest known mention of the painting comes from the inventory of the goods of Willem Fabricius (1709-1749), a member of the Haarlem city council and an alderman who had died on May 21, 1749 (figs. 2 and 3). On August 12 of that year, the picture, described as "a capital piece of painting by Potter," was found in the side room next to the entrance of Fabricius's house on Jansstraat (now number 55) in Haarlem. The décor of valuable paintings suggests that this side room functioned as a place for social gatherings in the Fabricius townhouse. ${ }^{5}$ As the inventory stated, the paintings in this and other rooms in the house were to be sold publicly; an auction catalogue was compiled for this purpose by the Haarlem painter and auctioneer Frans Decker (1684-1751). The auction took place only one week later, on August 19, in the premises of the Prinsenhof, adiacent to the Haarlem town hall, under Decker's guidance. ${ }^{6}$ 


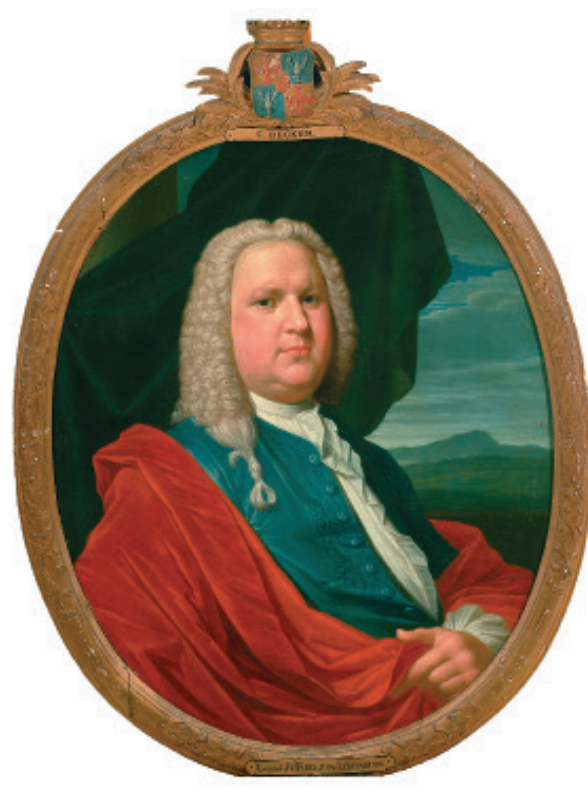

Fig. 2 Frans Decker, Portrait of Willem Albertsz Fabricius, 1742, oil on canvas, $78.5 \times 65 \mathrm{~cm}$, Frans Hals Museum, Haarlem, 0S-I-67

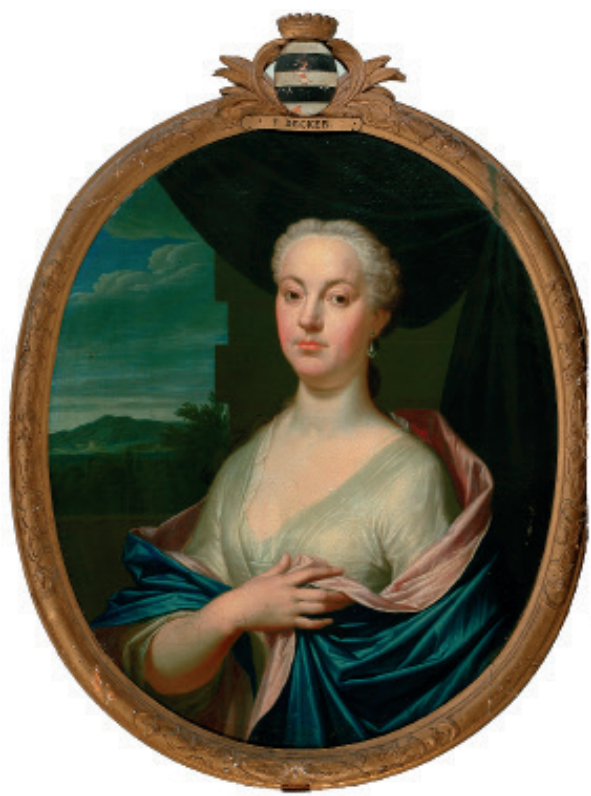

Fig. 3 Frans Decker, Portrait of Wilhelma Henriëtte Huygens, 1742, oil on canvas, 78.5 x 65 cm, Frans Hals Museum, Haarlem, 0S-I-68

Obviously, Potter's Bull was meant to attract as many buyers to the 1749 auction as possible, since it was sold as the very first lot. The auction catalogue described the piece as "an Extra Large and Capital piece ... by Paulus Potter 1647, being, in its fullness of detail, force, and naturalness, the most extraordinary piece known by this great master in this country." The work was sold to the auctioneer, Frans Decker, at fl. 630, a considerable sum at the time and by far the highest price in this auction, followed by a landscape and a flower piece by Jan van Huysum, a painting by Johannes Lingelbach, some paintings by Adriaen van Ostade, and Rembrandt's Abraham and Hagar, on which more will be said later in this article. ${ }^{8}$ In total, the sale of the fifty-seven paintings in this auction fetched a sum of fl. 6,319, while the library brought another fl. 3,879 to the estate.

5 The fact that Potter's Bull is mentioned in a 1754 list of paintings belonging to Princess Anna of Hannover, the widow of Prince William IV of Orange-hanging in the stadholder's quarters at the Binnenhof, The Hague-has always led to the reasonable supposition that the painting was acquired at the Fabricius sale by Decker on the prince's behalf. Sophie Drossaers and Theodoor Scheurleer, in their invaluable listing of the inventories of the possessions of the House of Orange between 1567 and 1795, even speak of "the spectacular purchase" by the prince of Potter's Bull. ${ }^{9}$ However, a manuscript annotation in a unique copy of the auction catalogue, kept in the archive of the Fabricius family, reveals that although the painting was, indeed, bought by Decker on commission, it was subsequently "given by the admiral Renst to the prince at his house te Loo." ${ }^{10}$

6 There can be little doubt that this reference to "admiral Renst" concerns Jacob Reynst (16851756), who made his career as an officer in the Amsterdam admiralty. Jacob Reynst was the son of Pieter Reynst, the secretary and later a member of the Haarlem town council as well as an alderman, and Catharina Hasevelt. Since his older brother was destined for a political career, 
Jacob decided to pursue a career in the navy. By 1713 he was a captain in the service of the Amsterdam admiralty; in 1744 he joined the higher ranks to become rear admiral (schout-bij-nacht), and in 1748 and 1750 he profited from a substantial-even, in the eyes of some of his contemporaries, extreme and unnecessary-increase in the number of promotions by the prince, first to the position of vice-admiral and, in 1750, to lieutenant-admiral. Reynst did not need the money that came with these promotions: he descended from a wealthy family, and his marriage to Eva Clifford (1695-1764), daughter of a banker, in 1718 was also very succesful in financial terms. ${ }^{11}$ When taxed in 1742, his annual income was estimated at fl. 12.000, thirty to forty times the average income of a craftsman at the time. Reynst and his wife lived in a house on one of the best parts of Keizersgracht in Amsterdam, at the corner of Vijzelstraat, together with five servants; we also know that he owned a carriage and four horses, all of which testify to his affluent lifestyle. ${ }^{12}$

$7 \quad$ Jacob Reynst belonged to a group of naval officers who firmly supported the cause of Prince William. ${ }^{13}$ The princes of Orange had been barred from the stadholderate in most of the provinces of the Republic after the death of king-stadholder William III in 1702. William III's nephew, Prince Willem Karel Hendrik Friso of Orange (1711-1751), who belonged to the Frisian branch of the family, became stadholder of Gelderland in 1722, of Groningen and Drenthe in 1729, and of Friesland in 1731. The wealthiest and most politically and economically important provinces of Holland, however-Zeeland and Utrecht_-did not accept him until 1747, when fear of a French invasion of the Republic helped to catapult the prince into the position of admiral-general and captain-general in the service of the Republic, and as stadholder William IV in all seven provinces. The stadholderate was declared hereditary in 1749 as a prelude to the monarchical position the house of Orange would take after the Batavian-French interlude, from 1813 until the present day. ${ }^{14}$

8 Thus, Jacob Reynst's career as a naval officer paralleled William IV's political and military career. Several letters in the Dutch Royal House Archives confirm the close relationship between the two men. Reynst presented Prince William with a horse (a "cornet") in 1745, and the prince returned the gift by sending Reynst an even better Spanish horse with full gear. Reynst thanked the prince for this magnanimous gesture while excusing himself: it had never been his intention, he wrote, "to catch a big fish by throwing small bait." ${ }^{15}$ Although this may have been true in the narrow sense of that particular exchange, it it clear that Jacob Reynst's purchase of Potter's Bull and his subsequent presentation of it to the prince in 1749 was only one step in a longer chain of exchanges of gifts and favors between the two, crowned by Reynst's nomination to the highest position within the admiralty in 1750 . The last thing Reynst could do in return, in 1751, was to accompany the prince's dead body to his tomb in New Church, Delft, as one of the four principal pallbearers (fig. 4).

9 Apparently, Reynst had wished that the painting would be placed in the "huys te Loo." This may refer to the palace, "het Loo," near Apeldoorn, originally a hunting castle for the family of Orange (in Dutch, loo means "forest"), but redesigned and rebuilt on a grand scale under king-stadholder William III of Orange. ${ }^{16}$ It may well be that Reynst intended Potter's Bull to join the other paintings that the young Prince William IV had gathered there in a gallery and a cabinet from 1733 onward. ${ }^{17}$ Many of those paintings were taken to The Hague in the 1760s and 1770s and 


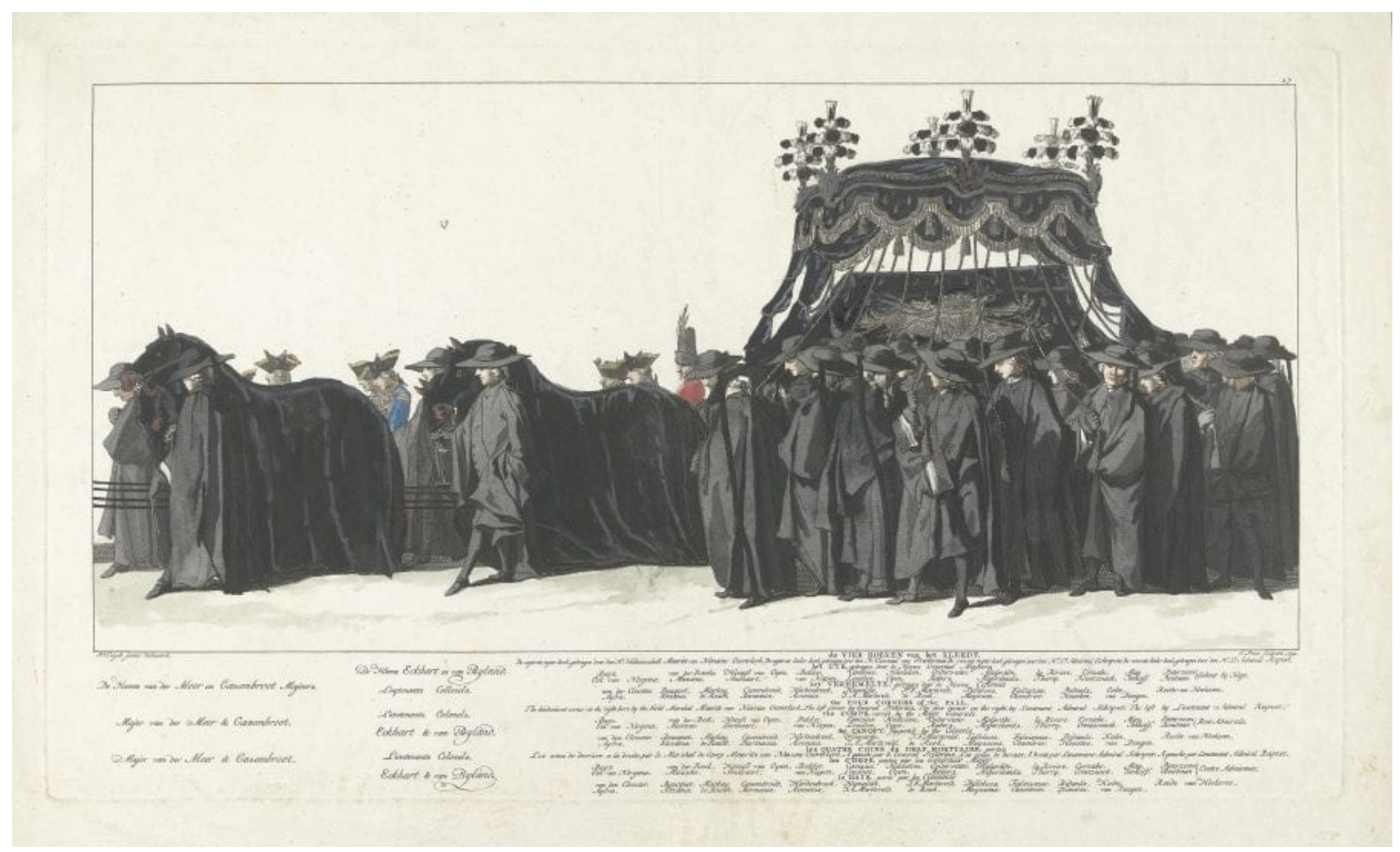

Fig. 4 Jan Punt after Pieter Jan van Cuyck, Funeral Procession of Prince William IV, with Jacob Reynst as a Pallbearer at the Left Front of the Coffin, 1754-55, etching, 27 x 56.5 cm, Rijksmuseum, Amsterdam, RP-P-1886-A-10908AA (artwork in the public domain)

were finally placed in the princely cabinet of paintings on the Buitenhof in $1774 .{ }^{18}$ Alternatively, Reynst may have meant the painting to be placed in one of the two smaller country houses that the stadholder had acquired in the vicinity of The Hague. In 1748, the prince-heedless of the risk of confusing later historians-had bought the estate of "de grote Loo," also called "het huys te Loo," ${ }^{19}$ and in 1749 the adiacent "kleine Loo," next to the Huis ten Bosch palace. While the house on "de grote Loo" was reshaped by William IV's architect Pieter de Swart into a playhouse, the grounds of "de kleine Loo" were transformed into the new seat of the princely menagerie, which was transported from "het Loo" near Apeldoorn to "de kleine Loo" near The Hague in 1749, the very same year that Jacob Reynst bought Potter's Bull in Haarlem and presented it to the stadholder. ${ }^{20}$ There are, however, no indications that the painting was ever placed in either "het Loo" or in the "grote" or "kleine Loo." The earliest mention that we have of Potter's painting as part of the prince's belongings dates from August 1754, when it could be found in one of the rooms of the princely quarters at the Binnenhof in The Hague, north of the former chapel. The painting is thought to have been taken there, together with other pictures, from the private rooms of the stadholder after his sudden death in $1751 .^{21}$

\section{Potter's Bull as a Family Heirloom}

10 While the above sheds new light on the trajectory of the Bull after its sale in 1749, the Fabricius family archives also contain valuable information on the painting's earlier whereabouts and ownership. Willem Fabricius was not the original collector of most of the paintings that were 
sold at auction after his death in 1749. According to his parents' will, his father Albert Fabricius (1676-1736), secretary of the Haarlem council, left all his paintings and his library to Willem in compensation for the jewelry given to Willem's only sister, Helena Wilhelma (1703-1743), on her marriage to Willem Six (1692-1757) in $1723 .{ }^{22}$ By the time Willem was engaged to marry Wilhelma Henrietta Huyghens (1713-1747), in the fall of 1732, a prenuptial agreement again specified that all the books and paintings that belonged to his father were destined to come into Willem's possession. ${ }^{23}$ Albert Fabricius made it clear that "Potter's Bull had already been given to his son [Willem]." In Albert Fabricius's final will of 1734, he revoked all stipulations in earlier testaments made by him or his late wife, with the explicit exception of his decision on the destination of his books and paintings. ${ }^{24}$

11 It may well be that Albert Fabricius had bought most of the pictures in his possession, either on his own account or in conjunction with his wife, Henriëtte Christine de Witt (1675-1724). This may have occurred around the time the couple bought and settled in their house on Jansstraat in 1704 (fig. 5). ${ }^{25}$ The house transferred to Willem upon his marriage in $1732,{ }^{26}$ together with Potter's Bull, and it was there, as we learned at the beginning of this article, that the painting was found in 1749.

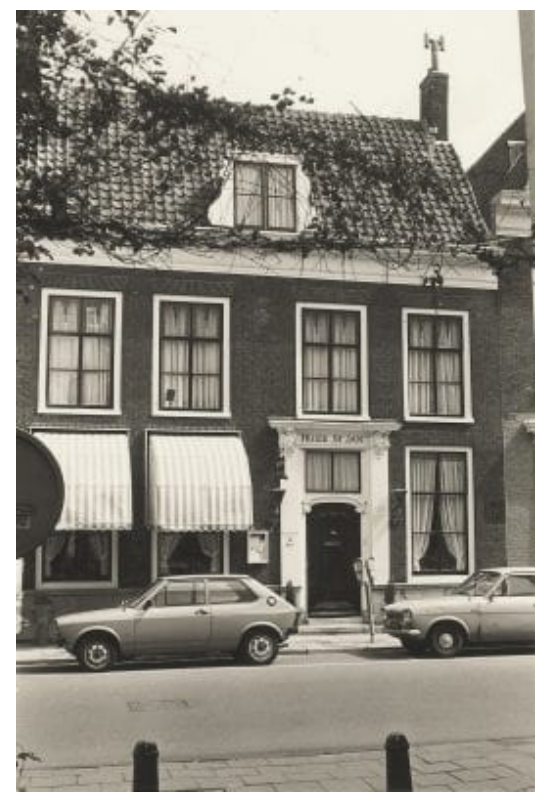

Fig. 5 Jansstraat 55, Haarlem, in the early 1980s, when the house served as a restaurant. In 1749 , Potter's Bull hung in the room to the right of the main entrance. Photo: E. J. Meertens, Noordhollands Archief, Haarlem

12 A brief glance at the complete list of paintings that were sold in 1749 confirms that the collection had a distinctly local touch. There were six paintings by Adriaen van Ostade; four by Cornelis Pietersz Bega; three by Dirck Maes; two paintings each by Nicolaes Pietersz Berchem, Jan Steen, Jan van Hugtenburg, Cornelis Dusart, Richard Brakenburgh, and Jan van der Meer; and single pictures by Philips Wouwerman, Adriaen Brouwer, and Adriaen van de Velde. All of these painters had been active in Haarlem-some of them all their lives, others only at a certain stage of their careers. Lingelbach, Herman Saftleven, Bartholomeus Breenbergh, Gerrit Dou, David Teniers, and Jan Asselijn, also listed in the catalogue, do not seem to match this profile. Two paintings by van Huysum may have been bought by either Albert Fabricius or his son Willem, although no mention of such a purchase is found in Willem's journal over the years $1737-44 .^{27}$ 
Given the predominance of painters who were active in Haarlem in the second half of the seventeenth century, it may be that even Albert was not the original purchaser of these pictures, but that they were already in the possession of his family. We know from the will of Albert Fabricius's mother that this is the case with at least three pictures, including Potter's Bull. When Barbara Schas (1654-1725), widow of former burgomaster Willem Fabricius Sr. (1642-1708) (figs. 6 and 7) made her will on December 25, 1724, she bequeathed all her movable possessions in the country estate of Santhorst, between Leiden and The Hague, to her oldest son, Arent, who had already taken possession of the property. To her second son, Albert Fabricius, however, she left "the large piece of painting by Potter, a small piece by Rembrandt and a small [painting of a] papist church," together with a damask tablecloth, eighteen napkins, and a towel, all already distributed to him, and 2,800 guilders in compensation for the marriage gift to his sister Barbara Cornelis. ${ }^{28}$ In an earlier version of her will, dated April 1, 1718, almost identical formulations are used, with the significant specification that the three paintings mentioned above were already in Albert's house on Jansstraat at the time. ${ }^{29}$

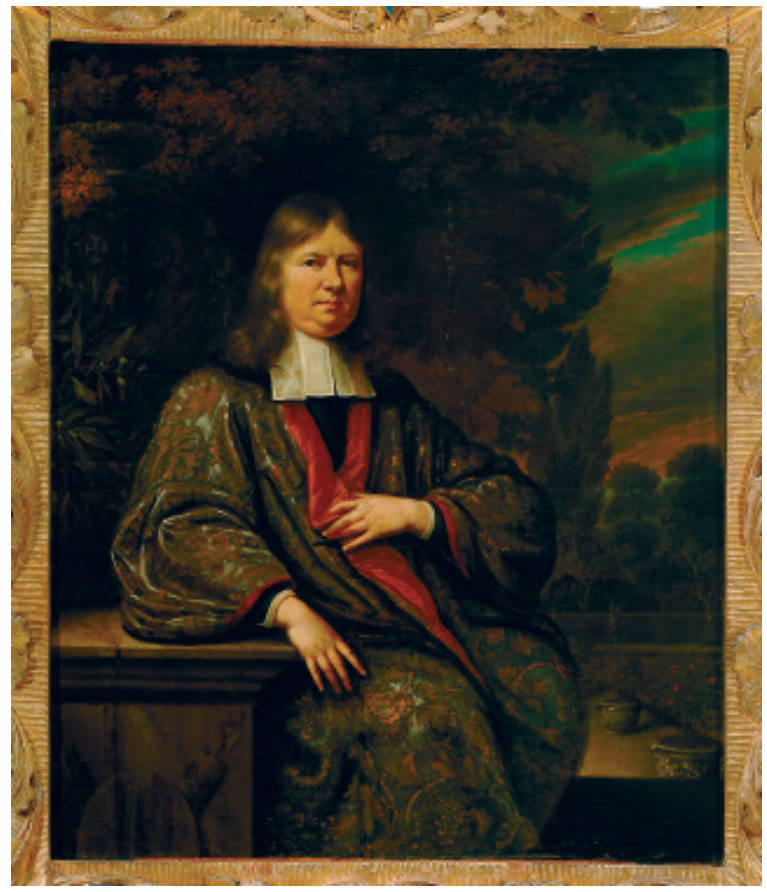

Fig. 6 Daniel Haringh, Portrait of Willem Fabricius, c. 1682, oil on canvas, 51 x $42 \mathrm{~cm}$, Frans Hals Museum, Haarlem, 0S-I-126

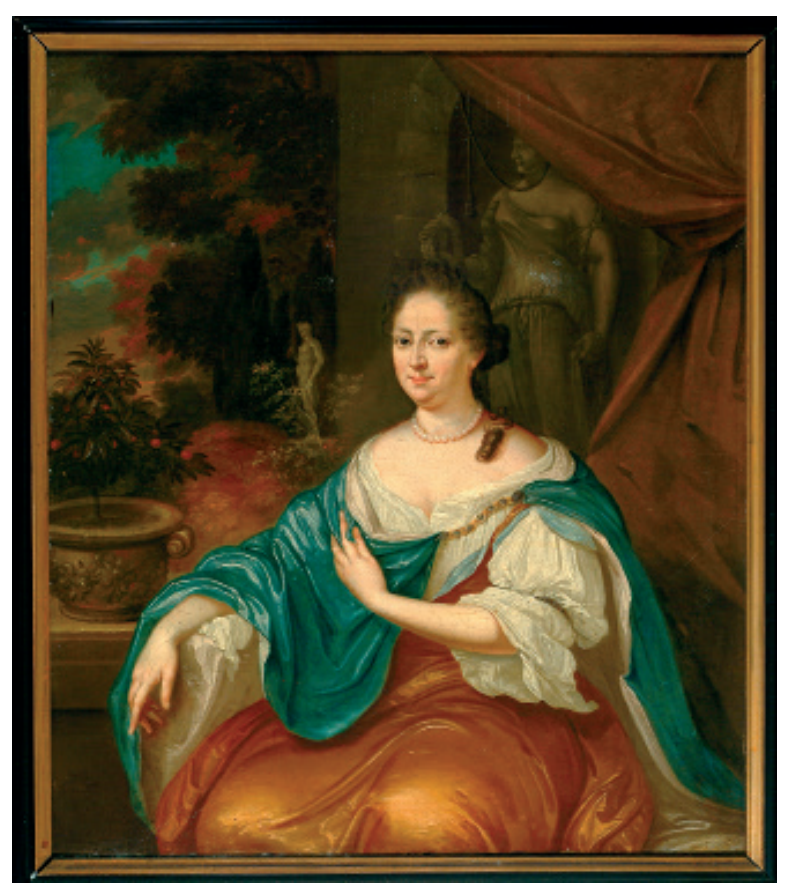

Fig. 7 Daniel Haringh, Portrait of Barbara Schas, c. 1682, oil on canvas, $53 \times 45 \mathrm{~cm}$, Frans Hals Museum, Haarlem, 0S-I-127

14 We do not know how Willem Fabricius and Barbara Schas came to acquire these three paintings and what exactly caused Barbara Schas to leave them specifically to her son Albert in her wills of 1718 and 1724. If her intent was to leave him something of financial value, she could have easily extracted the corresponding amount of money from her estate, which had been valued at a dazzling fl. 300,000 at the death of her husband in $1708 .{ }^{30}$ Presumably, there was also some other value, perhaps a sentimental one, at stake in her decision to leave the three paintings to her son. ing out Hagar, artfully and forcefully done, by Rembrand van Rhyn, 1 foot and 3 inches high, 1 
foot and 9 1/2 inch wide" (lot 12, fl. 320); and "The interior of a roman catholic church, artful, by P. Neefs, 1 foot 2 inches high, 10 inches wide" (lot 33, fl. 61-10 to La Roy). The Rembrandt picture has understandably been connected to a painting with the same subject of exactly the same size in the Victoria \& Albert Museum, London, now attributed to Rembrandt's workshop (fig. 8). However, since the painting sold in 1749 was already in the possession of the Fabricius family in 1718, the provenance of the work in the V\&A must be revised. ${ }^{31}$ Pieter Neefs's picture, with its unusual vertical fomat, may be a small panel of almost exactly the same size that is now in the Fondation Calvet, Avignon (fig. 9). ${ }^{32}$ But setting aside any ambiguities about the Rembrandt and Neefs, we can safely conclude that Potter's Bull was already in Haarlem in 1718-in the possession of Barbara Schas, the widow of Willem Fabricius Sr., but placed in the house of their son Albert Fabricius on Jansstraat, where it remained until the auction of the paintings belonging to Willem Fabricius Jr. in 1749.

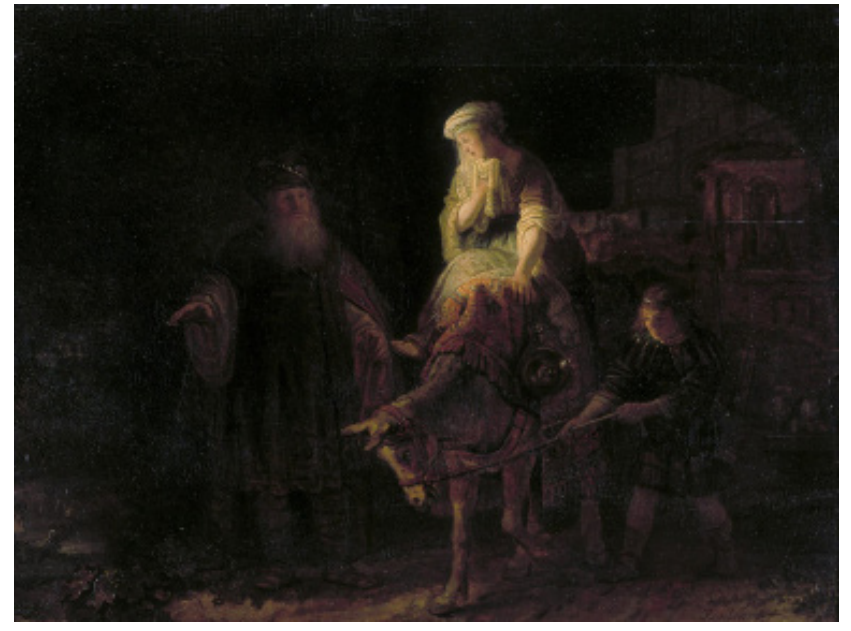

Fig. 8 Workshop of Rembrandt van Rijn, Abraham Sending Hagar and Ismaël Away (also erroneously known as The Departure of the Sunammite Woman), signed "Rembrandt 1640," 39 × $53.2 \mathrm{~cm}$, Victoria \& Albert Museum, London, CAl.78 (artwork in the public domain)

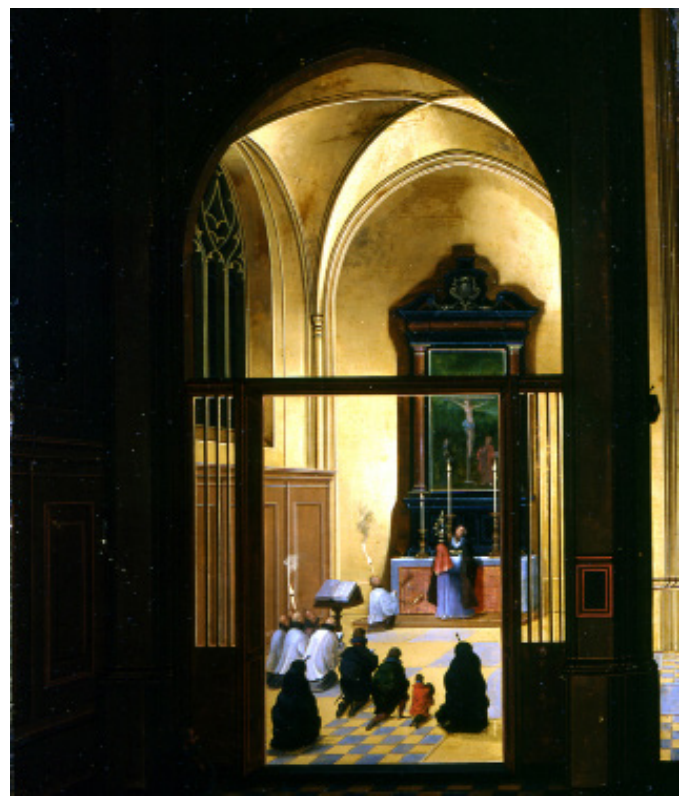

Fig. 9 Pieter Neefs I, Interior of a Chapel Where a Mass is Celebrated, oil on panel, $36.3 \times 27 \mathrm{~cm}$, Avignon, Fondation Calvet, 832.10

We do not know how Barbara Schas happened to acquire Potter's Bull, Rembrandt's Abraham and Hagar, and Neef's church interior. We do know that she was interested in porcelain and other goods that were imported from the Dutch East Indies, ${ }^{33}$ so it may be that she played a role in the acquisition of these paintings as well. It is also possible that the three paintings by Neefs, Potter, and Rembrandt (and maybe others) had been bought by her late husband, Willem Fabricius Sr. Although there is no specific mention of paintings in their prenuptial contract from February 19, 1670 , nor in their first will, from 1671, and a later one from 1698, this does not necessarily mean that there were no paintings in the household at the time. Besides, the wills state that the longest living member of the couple would inherit all their shared movable goods, with the exception of gold and silver coins, so Barbara Schas may very well have inherited the paintings from her husband at his death in $1708 .{ }^{34}$ Altogether, it seems likely that the paintings belonged to the common household of Willem Fabricius Sr. and Barbara Schas and may have already been in their house on Oude Gracht in Haarlem (fig. 10) before Willem Sr.s death in $1708 .{ }^{35}$ From there, they must 
have been taken to Jansstraat sometime between 1704 (when their son Albert Fabricius bought that house) and 1718 (when Barbara Schas said the three paintings by Potter, Rembrandt, and Neefs were there).

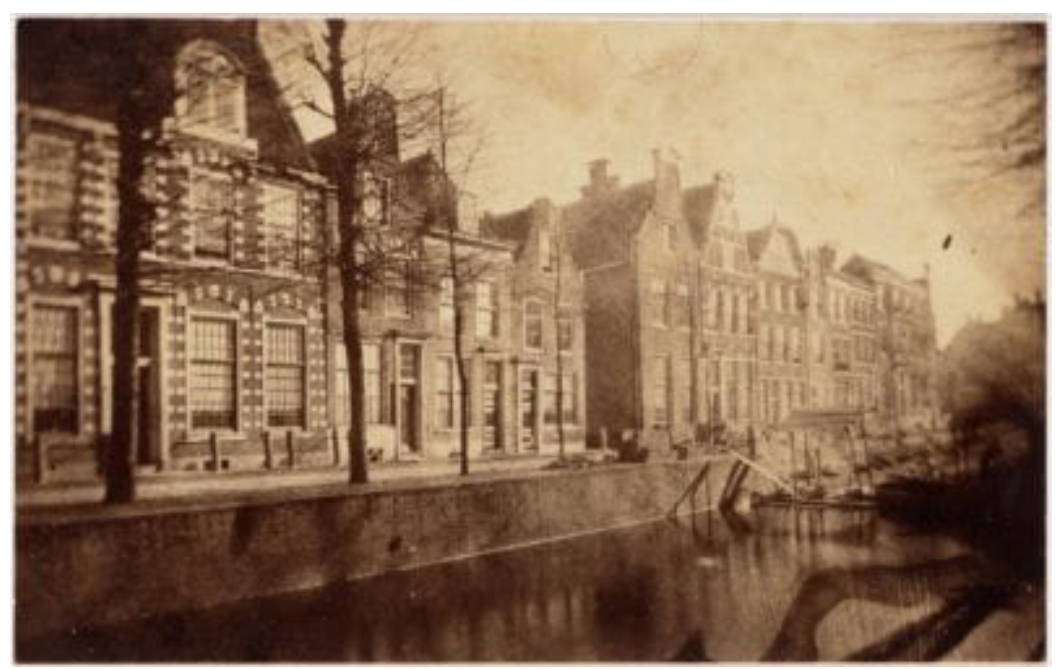

Fig. 10 Studio of Theodorus Johannes Munnich \& Robbert Carel Ermerins, Oude Gracht in Haarlem to the East, Near the Stoofsteeg (middle), Before the Canal was Filled In, photo, 1859, Noordhollands Archief, Haarlem. Beginning in 1669, Willem Fabricius owned two houses on Oude Gracht, one at the eastern (in this photo: the right hand) corner of Stoofsteeg (at the heart of this photo) and one down the adjacent small street. Potter's Bull hung in one of these houses before 1718 .

Both Willem Fabricius and Barbara Schas also brought a number of high-quality portraits from their respective families into their common household, most of which have ended up, through the Fabricius family, in the possession of the Frans Hals Museum, Haarlem. ${ }^{36}$ Among these are the pendant portraits of Willem Fabricius's uncle Anthonie Charles de Liedekercke (1587-1661) and his wife, Willemina van Braeckel (1604/5-1670), by Johannes Verspronck, and their family portrait, together with their son Samuel (1638-1655), by Gerard ter Borch (fig. 11). ${ }^{37}$ These portraits had been left by Willemina van Braeckel to her sister Judith, Willem Fabricius Sr's

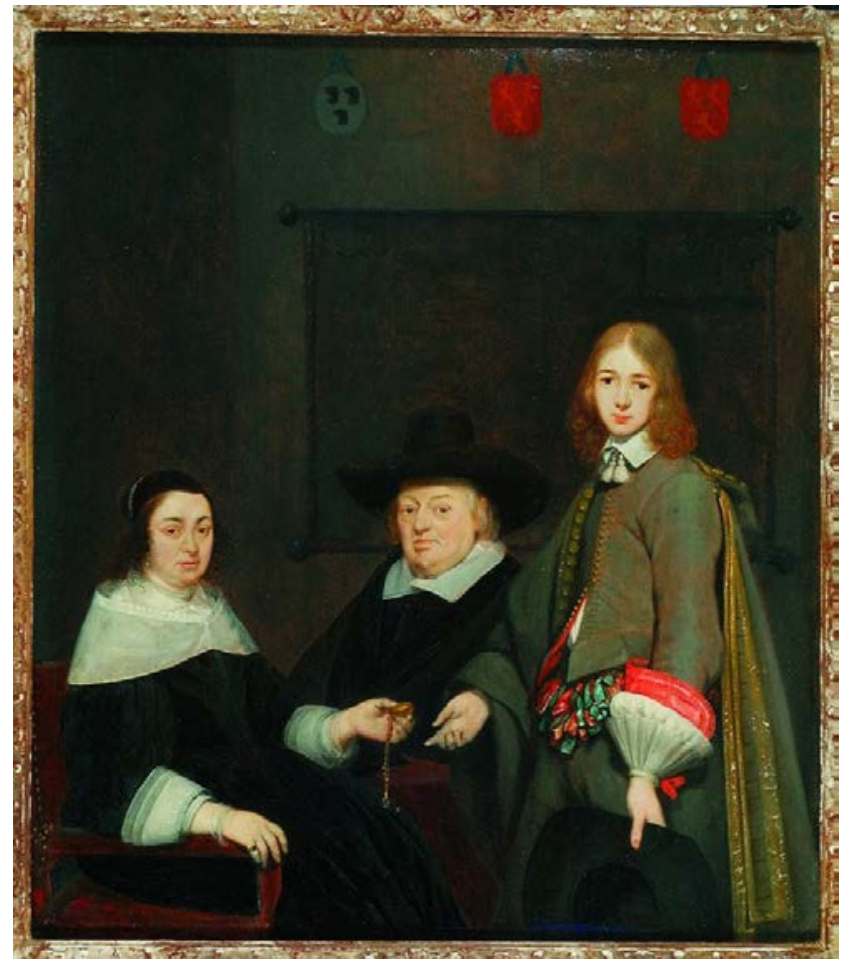

JHNA 13:1 (Winter 2021)
Fig. 11 Gerard ter Borch, Portrait of Judith van Braeckel, Anthonie Charles de Liedekercke, and Their Son Samuel, 1654-55, oil on canvas, $45 \times 39$ cm, Frans Hals Museum, Haarlem, 0S 1-28 
mother. Through her grandmother Cornelia van der Meer (1610-1668) and her mother, Cornelia Nierop (1633-1679), Barbara Schas had probably also inherited the portraits of her maternal great-grandparents Nicolaes Woutersz (Van der Meer) (1575-1637) and Cornelia Claes Vooght (1578-after 1637) by Frans Hals, now also in the Frans Hals Museum. ${ }^{38}$ All these portraits, and more, probably hung first in the Fabricius household on the Oude Gracht, and later in the house on Jansstraat. ${ }^{39}$

\section{The Earlier Provenance of the Bull: Room for Speculation}

We do not know for whom the Bull was painted (or adapted), nor do we know how it came into the possession of Barbara Schas and Willem Fabricius. However, an early provenance from The Hague, where the Schas and Nierop families were firmly established, seems much more likely than one from Haarlem. Paulus Potter registered as a member of Saint Luke's guild in Delft in August 1646, but there is no evidence that he ever produced a work of art in that town. Walsh suggests that the young painter may actually have lived with his parents in The Hague beginning in 1647, the same year his father, Pieter Sijmonsz Potter, registered with the guild there and in which Paulus Potter produced his Bull. In 1649, probably after his father gave up his membership in the Hague guild to leave for Amsterdam, Paulus Potter himself registered with Saint Luke's guild in The Hague. In the spring of 1652, he followed his father to Amsterdam, where both his father and mother passed away half a year later, and where Paulus Potter himself died early in $1654 .^{40}$

19 Could it be that the young Paulus Potter worked incidentally with, or for, his neighbor and father-in-law, the master carpenter and building contractor Claes Dircksz van Balckeneijnde (1599/1600-1664) ${ }^{{ }^{41}}$ This may well have been the case for The Bear Hunt, a picture of a similar size as the Bull (their widths differ by only $1 \mathrm{~cm}$ ) (fig. 12)..$^{42}$ Potter produced the Bear Hunt in 1649 , the very same year in which Balckeneijnde's new house and workplace on Dunne Bierkade (now no. 18) were completed. ${ }^{43}$ Potter's widow, Ariaentgen van Balckeneijnde (1626-1690),

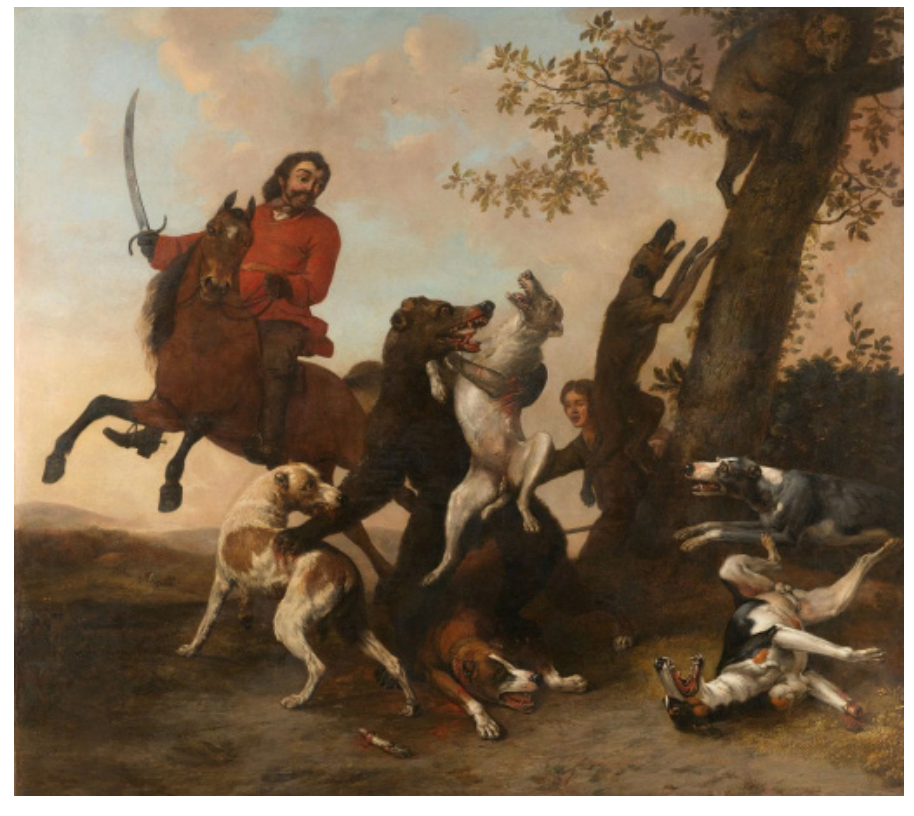

Fig. 12 Paulus Potter, The Bear Hunt, 1649, canvas, 305 x 338 cm, Rijksmuseum, Amsterdam SK-A-316 (artwork in the public domain).The painting was heavily restored in the nineteenth century. 
acquired Dunne Bierkade 18 in 1667 from her father's estate. The painting, in all probability, was in her possession at that time, and she subsequently kept it in her second husband's house on Paviljoensgracht in the Hague as a memento of her late husband, together with his (probably posthumous) portrait by Bartholomeus van der Helst. ${ }^{44}$

For the Bull, painted two years earlier, we cannot establish such a possible connection to a Balckeneijnde property, ${ }^{45}$ except for one. The settlement of the division of the estate of Claes Dircksz van Balckeneijnde in 1667 took place on two occasions before Albert Nierop (1600-1676), lawyer in the Hof van Holland in The Hague (fig. 13). ${ }^{46}$ Interestingly, Albert Nierop was also the maternal grandfather of Barbara Schas, the first documented owner of Potter's Bull. This may be purely coincidental, but it is at least theoretically possible that through these proceedings Nierop became aware of the existence and, possibly, the availability of the painting, and that he acquired it on this occasion. In that case, the painting would have descended to his daughter Cornelia Nierop (1633-1679) and subsequently to her daughter Barbara Schas, who brought it to Haarlem. But it is, of course, also perfectly possible that Nierop himself, or another of Barbara Schas's forebears, had commissioned Potter to create the Bull for one of their dwellings ${ }^{47}$

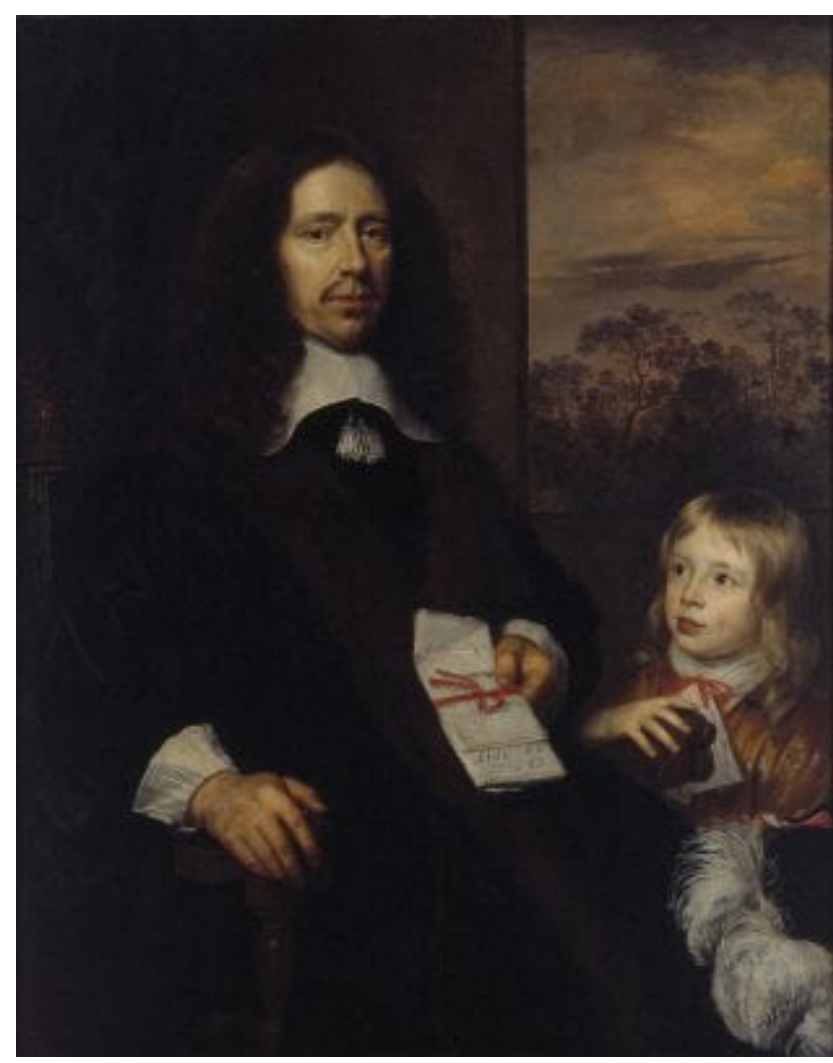

Fig. 13 Johannes Mijtens, Portrait of Albert Nierop (1600-1676) and His Grandson Albert Schas (1656-1719), 1663, canvas, 113 x $91 \mathrm{~cm}$, Rijksdienst Cultureel Erfgoed, Amersfoort, on loan to Museum Gouda, Gouda, inv. 55195

\section{The Trajectory of a Bull}

21 Now that we have come to the end of our journey back in time, uncovering some steps in the provenance of Paulus Potter's Bull, we realize, once more, that a painting like this, even if we feel familiar with its appearance as a museum piece (as it has been ever since the late eighteenth century), must have represented different modalities of function, meaning, and emotional associa- 
tion in its various stages of its existence.

22 Potter's Bull is, with all its baffling realism, nevertheless the work of a very young painter who had only recently registered as an independent master. As such, it must have made a smashing impression as a spectacular piece of decoration in a private house, whether in The Hague, in the immediate surroundings of the painter, or in the home of one of Barbara Schas's ancestors.

Next, it demonstrably served as an heirloom, together with paintings by Rembrandt and Neefs, with a special status within the respectable Schas and Fabricius families in The Hague and Haarlem. This tallies with a more general pattern of the bourgeois memory cult within the Dutch Republic, in which certain paintings were assigned to specific heirs by testamentary decisions, usually not so much for the sake of money as of personal memory. ${ }^{48}$ Apparently, Potter's Bull was such a painting.

24 The purchase of the painting by Jacob Reynst in 1749, and his subsequent gifting of the piece to the stadholder-probably in return for the favors that had been bestowed upon him by William IV in the preceding years-marks a transition in the function of this painting. Recently, scholars have demonstrated renewed interest in the phenomenon of gift giving and exchange as part of wider issues of allegiance and networking in the early modern period. We know that paintings incidentally functioned in this context, a practice that may look trivial from a modern perspective but must have enjoyed important meaning at the time. ${ }^{49}$ It was only because of the early death of the stadholder in 1751, and the following plans by his widow, Anna of Hannover, and his son Prince Willem V to arrange a public picture cabinet in The Hague, that this association of Potter's Bull with gift giving and family memory was lost rapidly. At that point, Potter's Bull became available for public viewing, allowing it to gain the national-indeed, international-renown it has enjoyed to the present day.

\section{Acknowledgements}

I wish to thank Quentin Buvelot and Niek van Sas for their comments on an earlier version of this text, as well as the two anonymous peer reviewers for their useful suggestions. Unless otherwise indicated, translations from the Dutch are mine.

Frans Grijzenhout holds the chair of Art History of the Early Modern Period at the University of Amsterdam. He has published widely on the relationship between art and politics in the seventeenth and eighteenth centuries. In his current research, he concentrates on issues of identification and meaning in Dutch seventeenth-century portraits and on aspects of memory in the Dutch Republic, as represented in contemporary artworks.

\section{f.grijzenhout@uva.nl}




\section{List of Illustrations}

Fig. 1 Paulus Potter, The Bull, oil on canvas, 236 x 339 cm, Mauritshuis, The Hague, inv. 136 (artwork in the public domain)

Fig. 2 Frans Decker, Portrait of Willem Albertsz Fabricius, 1742, oil on canvas, 78.5 x $65 \mathrm{~cm}$, Frans Hals Museum, Haarlem, OS-I-67

Fig. 3 Frans Decker, Portrait of Wilhelma Henriëtte Huygens, 1742, oil on canvas, 78.5 x $65 \mathrm{~cm}$, Frans Hals Museum, Haarlem, OS-I-68

Fig. 4 Jan Punt after Pieter Jan van Cuyck, Funeral Procession of Prince William IV, with Jacob Reynst as a Pallbearer at the Left Front of the Coffin, 1754-55, etching, 27 x $56.5 \mathrm{~cm}$, Rijksmuseum, Amsterdam, RP-P-1886-A-10908AA (artwork in the public domain)

Fig. 5 Jansstraat 55, Haarlem, in the early 1980s, when the house served as a restaurant. In 1749, Potter's Bull hung in the room to the right of the main entrance. Photo: E. J. Meertens, Noordhollands Archief, Haarlem

Fig. 6 Daniel Haringh, Portrait of Willem Fabricius, c. 1682, oil on canvas, 51 x $42 \mathrm{~cm}$, Frans Hals Museum, Haarlem, OS-I-126

Fig. 7 Daniel Haringh, Portrait of Barbara Schas, c. 1682, oil on canvas, 53 x 45 cm, Frans Hals Museum, Haarlem, OS-I-127

Fig. 8-1 Workshop of Rembrandt van Rijn, Abraham Sending Hagar and Ismaël Away (also erroneously known as The Departure of the Sunammite Woman), signed "Rembrandt 1640," 39 x 53.2 $\mathrm{cm}$, Victoria \& Albert Museum, London, CAI.78 (artwork in the public domain)

Fig. 9 Pieter Neefs I, Interior of a Chapel Where a Mass is Celebrated, oil on panel, $36.3 \times 27 \mathrm{~cm}$, Avignon, Fondation Calvet, 832.10

Fig. 10 Studio of Theodorus Johannes Munnich \& Robbert Carel Ermerins, Oude Gracht in Haarlem to the East, Near the Stoofsteeg (middle), Before the Canal was Filled In, photo, 1859, Noordhollands Archief, Haarlem. Beginning in 1669, Willem Fabricius owned two houses on Oude Gracht, one at the eastern (in this photo: the right hand) corner of Stoofsteeg (at the heart of this photo) and one down the adjacent small street. Potter's Bull hung in one of these houses before 1718.

Fig. 11 Gerard ter Borch, Portrait of Judith van Braeckel, Anthonie Charles de Liedekercke, and Their Son Samuel, 1654-55, oil on canvas, 45 x 39 cm, Frans Hals Museum, Haarlem, OS 1-28

Fig. 12 Paulus Potter, The Bear Hunt, 1649, canvas, 305 x 338 cm, Rijksmuseum, Amsterdam SKA-316 (artwork in the public domain).The painting was heavily restored in the nineteenth century. 
Fig. 13 Johannes Mijtens, Portrait of Albert Nierop (1600-1676) and His Grandson Albert Schas (1656-1719), 1663, canvas, 113 x $91 \mathrm{~cm}$, Rijksdienst Cultureel Erfgoed, Amersfoort, on loan to Museum Gouda, Gouda, inv. 55195

\section{Bibliography}

Bloys van Treslong, Paul Constant. Genealogische en heraldische gedenkwaardigheden in en uit de kerken der provincie Zeeland. Utrecht: A. Oosthoek, 1919.

Bok, Marten Jan, and Sebastien A. C. Dudok van Heel. "Frans Halsen" aan de muur: Omgang met familieportretten in Haarlem: Voocht-Olycan-Van der Meer. The Hague: Koninklijk Nederlandsch Genootschap voor Geslacht- en Wapenkunde, 2013.

Bruijn, Jacobus R. De Amsterdamse admiraliteit in rustige jaren, 1713-1751: Regenten en financiën, schepen en zeevarenden. Amsterdam: Gemeentelijke Archiefdienst, 1970.

Buvelot, Quentin. “A newly discovered letter to Arnold Houbraken on the life of Paulus Potter." The Burlington Magazine 157 (2015): 92-95.

Buijsen, Edwin, Charles Dumas and Erik Löffler. Haagse schilders in de Gouden Eeuw: Het Hoogsteder Lexicon van alle schilders werkzaam in Den Haag 1600-1700. The Hague: Kunsthandel Hoogsteder \& Hoogsteder, 1998.

Caland, Frederik. “Aitzema.” De Navorscher 46 (1896): 63-64. Catalogus van een keurlyk kabinet konstige en plaisante schilderyen, nagelaaten door wylen de wel ed: Gestrenge heer \& mr. Willem Fabricius. Haarlem: Jan Bosch, August 19, 1749.

Drossaers, Sophie W. A., and Theodoor H. Lunsingh Scheurleer. Inventarissen van de inboedels in de verblijven van de Oranjes en daarmede gelijk te stellen stukken, 1567-1795. Vol. 3, Inventarissen Nassau-Oranje 1763-1795 Registers en Indices. The Hague: Nijhoff, 1975.

Dumas, Charles. Haagse stadsgezichten 1550-1800: Topografische schilderijen van het Haags Historisch Museum. Zwolle: Waanders, 1991.

Ekkart, Rudi E. O., and Claire van den Donk. Lief en Leed: Realisme en fantasie in Nederlandse familiegroepen uit de zeventiende en achttiende eeuw. Zwolle: Waanders, 2018.

Elias, Johan E. De vroedschap van Amsterdam, 1578-1795. Amsterdam: N. Israel, 1963. Everdingen, Louise van. Het Loo, de Oranjes en de jacht. Haarlem: Joh. Enschedé, 1984.

Eijnden, Roeland van, and Adriaan van der Willigen, Geschiedenis der vaderlandsche schilderkunst. 4 vols. Haarlem: A. Loosjes, 1817-1840.

Gabriëls, Jos. De heren als dienaren en de dienaar als heer: het stadhouderlijk stelsel in de tweede helft van de achttiende eeuw. The Hague: Stichting Hollandse Historische Reeks, 1990. 
Grijzenhout, Frans, Cultureel erfgoed in revolutie en restauratie. Amsterdam: Amsterdam University Press, 2004.

Grijzenhout, Frans. Pro memorie: Een Gouden Eeuw als erfenis. Nijmegen: Vantilt, 2011.

Halma, François. Tooneel der Vereenigde Nederlanden, en onderhorige landschappen, geopent in een algemeen historisch, genealogisch, geographisch, en staatkundig woordenboek. Leeuwarden: Hendrik Halma, 1725.

Hees, C. A. van. "Identificatie van de zg. Colenbergh/van Braeckelportretten in het Frans Halsmuseum te Haarlem." Oud Holland 74 (1959): 233-36. https://doi.org/10.1163/187501759x00764

Heal, Felicity. The Power of Gifts: Gift-Exchange in Early Modern England. Oxford: Oxford University Press, 2014.

Hoes, Johannes. “'Het vee zooals het is en niet anders': De reputatie van Paulus Potter (16251654)." In Meesterlijk vee: Nederlandse veeschilders 1600-1900, edited by Cees Boschma et al., 87-100. Zwolle: Waanders, 1988.

Hoet, Gerard. Catalogus of naamlyst van schilderyen, met derzelver pryzen zedert een langen reeks van jaaren zoo in Holland als op andere plaatzen in het openbaar verkogt . . The Hague: Pieter Gerard van Baalen, 1752.

Houbraken, Arnold. De groote schouburgh der Nederlantsche konstschilders en schilderessen. 3 vols. Amsterdam: Arnold Houbraken, 1718-1721.

Immerzeel, Johannes. De levens en werken der Hollandsche en Vlaamsche kunstschilders, beeldhouwers, graveurs en bouwmeesters van het begin der vijftiende eeuw tot heden. 3 vols. Amsterdam: Gebroeders Diederichs, 1842.

Jagtenberg, Fred J. A. Willem IV: Stadhouder in roerige tijden 1711-1751. Nijmegen: Vantilt, 2018.

Janssen, Geert H. Princely Power in the Dutch Republic: Patronage and William Frederick of Nassau (1613-64). Manchester: Manchester University Press, 2008.

Jonge, Johannes Cornelis de, and Jan Karel Jacob de Jonge. Geschiedenis van het Nederlandsch zeewezen. 5 vols. Haarlem: A. C. Kruseman, 1858-64.

Jongste, Jan A. F. de. Onrust aan het Spaarne: Haarlem in de jaren 1747-1751. Dieren: De Bataafsche Leeuw, 1984.

Krausman Ben-Amos, Ilana. The Culture of Giving: Informal Support and Gift-Exchange in Early Modern England. Cambridge: Cambridge University Press, 2008. 
Kooijmans, Luuc. Vriendschap en de kunst van het overleven in de zeventiende en achttiende eeuw. Amsterdam: Bert Bakker, 1997.

Kooijmans, Luuc. Liefde in opdracht: Het hofleven van Willem Frederik van Nassau. Amsterdam: Bert Bakker, 2000.

Loughman, John, and John Michael Montias. Public and Private Spaces: Works of Art in Seventeenth-Century Dutch Houses. Zwolle: Waanders, 2000.

Lugt, Frits. Répertoire des catalogues de vente publiques intéressant l’art ou la curiosité . . . 4 vols. The Hague: Martinus Nijhoff, 1938-1989.

Maillet, Bernard G. Intérieurs d'églises: La peinture architecturale des écoles du nord, 1580-1720. Brasschaat: Petraco Pandora, 2012.

Oldewelt, Willem F. H. Kohier van de personeele quotisatie te Amsterdam over het jaar 1742. 2 vols. Amsterdam: Amsterdam Genootschap Amstelodamum, 1945.

Schmidt, Freek H. Pieter de Swart: Architect van de achttiende eeuw. Zwolle: Waanders, 1999.

Sliggers, Bert C., and Anneke A. Wertheim. Een vorstelijke dierentuin: De menagerie van Willem V. Zutphen: Walburg Pers, 1994.

Ufer, Ulrich. Welthandelszentrum Amsterdam: Globale Dynamik und modernes Leben im 17. Jahrhundert. Stuttgarter Historische Forschungen 8. Cologne: Böhlau, 2008.

Walsh, Amy, Edwin Buijsen, and Ben Broos. Paulus Potter: Schilderijen, tekeningen en etsen. Zwolle: Waanders, 1994.

Westrheene, Tobias van. Paulus Potter: Sa vie et ses oeuvres. The Hague: Nijhoff, 1867. Zandvliet, Kees. De rijksten van de Republiek: Rijkdom, geloof, macht en cultuur. Zutphen: Walburg Pers, 2018.

${ }^{1}$ On Potter's reputation, see Johannes Hoes, “Het vee zooals het is en niet anders': De reputatie van Paulus Potter (1625-1654)," in Meesterlijk vee: Nederlandse veeschilders 1600-1900, ed. Cees Boschma et al. (Zwolle: Waanders, 1988), 87-100.

${ }^{2}$ Sophie W. A. Drossaers and Theodoor H. Lunsingh Scheurleer, Inventarissen van de inboedels in de verblijven van de Oranjes en daarmede gelijk te stellen stukken, 1567-1795, vol. 3, Inventarissen Nassau-Oranje 1763-1795 Registers en Indices (The Hague: Nijhoff, 1975), 224; Frans Grijzenhout, Cultureel erfgoed in revolutie en restauratie (Amsterdam: Amsterdam University Press, 2004).

${ }^{3}$ Amy Walsh, Edwin Buijsen, and Ben Broos, Paulus Potter: Schilderijen, tekeningen en etsen (Zwolle: Waanders, 1994), 74-77. 
${ }^{4}$ Walsh, Buijsen, and Broos, Paulus Potter, 76.

5 "Een capitaal stuk schilderij van Potter," inventory of the goods left by Willem Fabricius Jr., August 12, 1749, notary Willem Baart, 894, act 18, fol. 29v, Oud Notarieel Archief (ONA) Haarlem, Noord-Hollands Archief, Haarlem. Unless otherwise stated, all documents cited in this article are in the Noord-Hollands Archief, Haarlem. A list of paintings in this inventory can be found in the Getty Provenance Index, Archival Inventory N-6285. A copy of this act is in the Fabricius family archive (hereafter "FA"), 82. On the function of the side room, see John Loughman and John Michael Montias, Public and Private Spaces: Works of Art in Seventeenth-Century Dutch Houses (Zwolle: Waanders, 2000), 53-60.

${ }^{6}$ An announcement of the auction appears in the Haerlemsche Courant, August 8, 1749. For the catalogue, with prices, see Gerard Hoet, Catalogus of naamlijst van schilderijen, met derzelver prijzen zedert een langen reeks van jaaren zoo in Holland als op andere plaatzen in het openbaar verkogt... (The Hague: Pieter Gerard van Baalen, 1752), 2:263-267; Frits Lugt, Répertoire des catalogues de vente publiques intéressant l'art ou la curiosité ... (The Hague: Martinus Nijhoff, 1938), 1:no. 709.

${ }^{7}$ Catalogus van een keurlyk kabinet konstige en plaisante schilderyen, nagelaaten door wylen de wel ed: Gestrenge heer \& mr. Willem Fabricius (Haarlem: Jan Bosch, August 19, 1749), lot 1, Fabricius FA, 83: "Een Extra Groot en Kapitaal stuk ... door Paulus Potter 1647. Zynde dit stuk in uitvoerigheid, kragt en natuurlykheid het byzonderste hier te lande van hem bekend." There are prices for all lots in this copy, but only three other names of buyers. Here one finds also the auction catalogues of his books (Haarlem: Johannes Bosch, August 14-15, 1749) and of the jewels, pearls, gold, silver and medals (Haarlem: Jan Bosch, August 19, 1749). Another copy of the auction catalogue for the paintings, with prices only, can be found in documents related to the estate of Willem Fabricius Jr., 1741-1780, Fabricius FA, 81.

${ }^{8}$ See the copy of the auction catalogue in the Bibliothèque Nationale de France, Paris, Yd-507 (4), fully annotated with prices and names of buyers. Roeland van Eijnden and Adriaan van der Willigen were the first to draw attention to the Fabricius sale in connection to the Bull; they also mention Frans Decker as the purchaser of the piece. Roeland van Eijnden and Adriaan van der Willigen, Geschiedenis der vaderlandsche schilderkunst (Haarlem: A. Loosjes, 1840), 4:152.

${ }^{9}$ Drossaers and Scheurleer, Inventarissen, 1:xxxvii, and 2:480.

${ }^{10}$ Catalogus van een keurlyk kabinet, lot 1: "Dekker in commissie en van mijn heer d'admiraal Renst aan de Prins present gedaan op 't huys te Loo" and "fl. 630."

${ }^{11}$ On him, see Johan E. Elias, De vroedschap van Amsterdam, 1578-1795 (Amsterdam: Israel, 1963) 1:369-72, no. 122 (Hendrick Reynst); Johannes Cornelis de Jonge and Jan Karel Jacob de Jonge, Geschiedenis van het Nederlandsch zeewezen (Haarlem: Kruseman, 1861), 4:144, 173-79, 226, 294; Jacobus R. Bruijn, De Amsterdamse admiraliteit in rustige jaren, 1713-1751: Regenten en financiën, schepen en zeevarenden (Amsterdam: Gemeentelijke Archiefdienst, 1970), 30, 100, 107, $112,118,127-128,130$. Reynst's portrait by Frans Decker (the auctioneer of the 1749 Haarlem auction) is in the Amsterdam Museum, SA 27227.

${ }^{12}$ Willem F. H. Oldewelt, Kohier van de personeele quotisatie te Amsterdam over het jaar 1742 (Amsterdam: Amsterdam Genootschap Amstelodamum, 1945), 2:321.

${ }^{13}$ Jan A. F. de Jongste, Onrust aan het Spaarne: Haarlem in de jaren 1747-1751 (Dieren: De Bataafsche Leeuw, 1984), 260.

${ }^{14}$ On William IV, recently, see Fred J. A. Jagtenberg, Willem IV: Stadhouder in roerige tijden 1711-1751 (Nijmegen: Vantilt, 2018), esp. 533ff. 
${ }^{15}$ Jacob Reynst to Prince William IV, May 1, 1745 (no. 173) Royal House Archives, The Hague:

"Men magh wel seggen dit is een spieringkje uijtgegoeijt om een cabeljauw te vangen." Cf. Bruijn, Amsterdamse admiraliteit, 130.

${ }^{16}$ Louise van Everdingen, Het Loo, de Oranjes en de jacht (Haarlem: Enschedé, 1984), 60-104.

${ }^{17}$ Drossaer and Scheurleer, Inventarissen, 1:xxxiii; Jagtenberg, Willem IV, 401-2.

${ }^{18}$ Drossaers and Scheurleer, Inventarissen, 1:xxxvii.

${ }^{19}$ François Halma, Tooneel der Vereenigde Nederlanden, en onderhorige landschappen, geopent in een algemeen historisch, genealogisch, geographisch, en staatkundig woordenboek... (Leeuwarden: Hendrik Halma, 1725), 56-57.

${ }^{20}$ Freek H. Schmidt, Pieter de Swart: Architect van de achttiende eeuw (Zwolle: Waanders, 1999), 106, 109, 119-120. On the menagerie, see Bert C. Sliggers and Anneke A. Wertheim, Een vorstelijke dierentuin: De menagerie van Willem V (Zutphen: Walburg Pers, 1994).

${ }^{21}$ Drossaers and Scheurleer, Inventarissen, 2:21.

${ }^{22}$ Testament of Albert Fabricius and Henriëtte Christine de Witt, Haarlem, June 25, 1723 (notary Jan van Dijk), Fabricius FA, 61.

${ }^{23}$ Inventory of the goods that Mr. Willem Fabricius will bring into his marriage, Haarlem, October 17, 1732, Fabricius FA, 75, final page, verso: “Further, by his father's and mother's mutual will, instead of the jewels that were given to their daughter at her marriage, all the books and paintings that I possess were bequeathed to his lordship, of which Potter's Bull had already been handed over to my son" (Nogh is den heer van Santhorst bij de mutuele testamente van sijn vader en moeder tot plaetsvulling van de juweelen bij deselven aen haer dogter mede ten huwelijk gegeven, gemaekt alle de boeken en de schilderijen die ik ben besittende, sijnde den Bull van Potter reets aen mijn soon overgegeven). See also the prenuptial agreement of the same date, with reference to this list, and another list of goods brought into the marriage by Willem Fabricius, November 12,1732, in the same inventory.

${ }^{24}$ Testament of Albert Fabricius, The Hague, December 1, 1734, notary Jacobus Pals, Fabricius FA, 65: “. . on the condition that everything the testator and his deceased wife have stated in their former disposition as to the bequest of the books and paintings to their son, will remain in effect" (mits noghtants geconserveert blijvende, het geene bij hem heer testateur ende zijn vrouw $\mathrm{zal}$ [iger] omtrent de boeken en schilderijen aan zijn heer testateurs zoon bij vorige dispositie is gemaakt).

${ }^{25}$ Register of the legal transfer of ownership of properties, Oud Rechterlijk Archief Haarlem, 353, fol. 13v, January 16, 1704.

${ }^{26}$ Testament of Albert Fabricius and Henriëtte Christine de Witt.

${ }^{27}$ Cash register of Willem Fabricius Jr, 1737-44, Fabricius FA, 77.

${ }^{28}$ Testament of Barbara Schas, Haarlem, December 25, 1724, notary Cornelis Baart, Fabricius

FA, 55: “ . . the big piece by Potter, a small piece by Rembrandt, and a little papist church, as well as the damask table cloth, eighteen napkins and a towel, all already transferred to his lordship" (het groote stuk schilderij van Potter, een stukkie van Rembrand, en een kleijn papekerkie, item het damast tafellaken, met agtien servetten en een handwael, alle sijn Ed. reets overgegeven). ${ }^{29}$ Testament of Barbara Schas, Haarlem, April 1, 1718, notary Cornelis Baart, ONA Haarlem, 618, act 57: "The testatrix also bequeaths by preference and promises to her second son Mr. Albert Fabricius, pensionary in this town, the large piece by Potter, a small piece by Rembrandt and a small papist church, all in his house" (Item prelegateert ende bespreeckt sij testatrice aen haer tweede soon d'hr mr Albert Fabricius, raed pensionaris alhier, het groote stuck schilderij 
van Potter, een stuckgen van Rembrant ende een klijn papekerckje, allen sijnde, te sijnen huijse). ${ }^{30}$ Inventory of the common possessions of Willem Fabricius and Barbara Schas, Haarlem, December 31, 1708, notary Pieter Gerlings, Fabricius FA, 53 (various documents concerning the possessions of Willem Fabricius Sr. and Barbara Schas, 1670-1713).

${ }^{31}$ The painting from the Fabricius sale cannot be identical to a painting by Rembrandt with the same subject that is listed as belonging to Adriaen Bout in 1734, or to the picture that was sold for forty-two guilders at auction in Amsterdam on April 15, 1739, as suggested in "Abraham dismissing Hagar and Ishmael: Object history note," Victoria \& Albert Museum, London, inv. CAI. 78; V\&A Search the Collections, accessed July 25, 2019, HTTP://COLLECTIONS.VAM. AC.UK/ITEM/O81365/ABRAHAM-DISMISSING-HAGAR-AND-ISHMAEL-OIL-PAINTINGREMBRANDT-VAN-RIJN.

${ }^{32}$ Bernard G. Maillet, Intérieurs d'églises: La peinture architecturale des écoles du nord, 1580-1720 (Brasschaat: Petraco Pandora, 2012), no. M-0842.

${ }_{33}^{3}$ Barbara Schas to Benjamin Burlamacchi and his wife, Wilhelmina van der Hoop, The Hague, August 30, 1684, and Haarlem, November 23, 1689, City Archives Amsterdam, Burlamacchi FA, 818; see also Ulrich Ufer, Welthandelszentrum Amsterdam: Globale Dynamik und modernes Leben im 17. Jahrhundert, Stuttgarter Historische Forschungen 8 (Cologne: Böhlau, 2008), 289-90.

${ }^{34}$ Prenuptial agreement between Willem Fabricius Sr. and Barbara Schas, February 19, 1670, and testament of Willem Fabricius and Barbara Schas, Haarlem, June 14, 1698, notary Pieter Gerling, Fabricius FA, 53. The 1698 testament is also in ONA Haarlem, no. 555, act 136. See also Testament of Willem Fabricius Sr. and Barbara Schas, Haarlem, January 15, 1671, notary Albert de Clercq, ONA Haarlem, 411, act 9, and codicil of Willem Fabricius and Barbara Schas to their testament of January 15, 1671, Haarlem, November 28, 1681, notary Pieter Baes, ONA Haarlem, 474 , act 197.

${ }^{35}$ These houses were transferred to Willem Fabricius by his aunt Willemina van Braeckel; see ONA The Hague, 297, fol. 33, May 17, 1669, notary Johannes Houttuyn, Municipal Archive, The Hague.

${ }^{36}$ Documents concerning the donation of his art collection by Johan Carel Willem Fabricius van Leijenburg to the Municipal Museum of Haarlem, 1882-84, Library Noord-Hollands Archief, Haarlem, 8135; documents concerning the family portraits and papers that were bequeathed by J. C. W. Fabricius van Leyenburg to the city of Haarlem, 1881-93, Fabricius FA, 126.

${ }^{37}$ It has always been a bit of a mistery when and where exactly this son Samuel died. Since he registered for Leiden University in the fall of 1654 but was not named in his parents' will, made up in Leiden on July 28, 1655, it has been assumed that he died in between. However, his burial record had never been found; see C. A. van Hees, "Identificatie van de zg. Colenbergh/van Braeckelportretten in het Frans Halsmuseum te Haarlem," OudHolland 74 (1959): 233-36 HTTPS://DOI.ORG/10.1163/187501759×00764; and, recently, Rudi E. O. Ekkart and Claire van den Donk, Lief en Leed: Realisme en fantasie in Nederlandse familiegroepen uit de zeventiende en achttiende eeuw (Zwolle: Waanders, 2018), 112-13. Thanks to the relationship between the Liedekercke and Fabricius families, we are finally able to solve this issue. From the December 31, 1708, inventory of the goods of Willem Fabricius Sr. and Barbara Schas (Fabricius FA, 53) and the register of goods belonging to Willem Fabricius and Barbara Schas (1708-1712; Fabricius FA, 54), it appears that Willem Fabricius Sr. had been the owner of a grave in the choir of the church of Voorburg (fourth row, third grave), which had come to him from his uncle, Captain Charles de Liedekercke, and was decorated with the captain's coat of arms and that of his son Samuel. The 
tomb indeed appears in the registry of ownership of graves at the church of Voorburg (c. 16301770; Archive of the Reformed Church Voorburg [ca. 1450-1970], 629, Municipal Archive, The Hague). The exact burial date of the boy can be found in the Annual account of the church masters, August 1, 1654-July 31, 1655, fol. 35v, Ibidem, 652: "A son of Anthonij Charles de Liedekercke, buried in the choir in the evening. 93 guilders paid for the purchase of the grave, 6 for the right to open it, and 1 guilder for the cloth, total 100 guilders" (Een soon van d'heer Anthonij Charles de Liedekercke den XXX Julij [1655] opt Choor bij avont begraven. Betaelt voor de coop vant graff XCIII gul[den], voort recht vant openen VI gul[den] ende voort cleet XX st[u]i[ve]rs, samen C guld[en]). Obviously, the testament of his parents of July 28, 1655, was made up immediately after their son's death in Leiden and two days before his burial in Voorburg. In the art-historical literature, there has also been a question as to Willemina van Braeckel's whereabouts after the death of her first husband, Anthonie Charles de Liedekercke, in 1661. In 1662, she married Anselmus van Aitsema, commander of the Moerschans near the fortified town of Hulst, near the border between the Dutch Republic and Spanish Flanders, and died in Hulst on February 14, 1670; her second husband died on December 10 of the same year. See Frederik Caland, "Aitzema," De Navorscher 46 (1896): 63-64; and Paul Constant Bloys van Treslong, Genealogische en heraldische gedenkwaardigheden in en uit de kerken der provincie Zeeland (Utrecht: A. Oosthoek, 1919), 96.

${ }^{38}$ Marten Jan Bok and Sebastien A. C. Dudok van Heel, "Frans Halsen" aan de muur: Omgang met familieportretten in Haarlem, Voocht-Olycan-Van der Meer (The Hague: Koninklijk Nederlandsch Genootschap voor Geslacht- en Wapenkunde, 2013), 41-49.

${ }^{39}$ The 1749 inventory mentions forty-three portraits, most of them unspecified. Inventory of the goods left by Willem Fabricius Jr., August 12, 1749.

${ }^{40}$ Amy Walsh, "Het leven van Paulus Potter (1625-1654)," in Walsh, Buijsen, and Broos, Paulus Potter, 10-19; Edwin Buijsen, Charles Dumas, and Erik Löffler, Haagse schilders in de Gouden Eeuw: Het Hoogsteder Lexicon van alle schilders werkzaam in Den Haag 1600-1700 (The Hague: Kunsthandel Hoogsteder \& Hoogsteder, 1998), 225-29; Q. Buvelot, "A Newly Discovered Letter to Arnold Houbraken on the Life of Paulus Potter," The Burlington Magazine 157 (2015), 92-95. ${ }^{41}$ On the authority of Nicolaes van Reenen, a son from the second marriage of Potter's widow, Arnold Houbraken relates how Balckeneijnde introduced his son-in-law to elite circles in The Hague. Arnold Houbraken, De groote schouburgh der Nederlantsche konstschiilders en schilderessen (Amsterdam: 1718-1721), 2:127.

${ }_{2}^{42}$ Walsh, Buijsen, and Broos suggest that the painting was intended for a country estate in the neighborhood of The Hague, but that it was left unsold because of its unsatisfactory composition. Walsh, Buijsen, and Broos, Paulus Potter, 111-114.

${ }^{43}$ On Balckeneijnde's properties, and specifically Dunne Bierkade 18, see Van Westrheene, Potter, 51-56 and 136-138. Balckeneijnde bought the two lots to build his house and "werckhuijs" on Dunne Bierkade on July 28, 1640. According to the register of newly built or modified houses since 1632 (c. 1655; Sociëteit Den Haag, 135, fol. 57v, Municipal Archive, The Hague), both buildings were completed in 1649. There is no evidence that this house was built in 1638, as some websites maintain, nor that it was designed by Pieter Post, as claimed, for example, in Charles Dumas, Haagse stadsgezichten 1550-1800: Topografische schilderijen van het Haags Historisch Museum (Zwolle: Waanders, 1991), 509. Papers in the Voorhoeve family archive (138 and 139, Municipal Archive, The Hague), give detailed measurements of Dunne Bierkade 18, taken before the interior was partly restructured in the 1970s. At that time, the size and distribution of the 
rooms were still very close, if not identical, to the seventeenth-century plan. This is confirmed by the inventory of the goods of the late Hendrick Heuck, who lived in the house from 1676 to 1678 (ONA The Hague, 828, 71-96 and 97-147). It is interesting to note that the height of most of the rooms on the main floor was about $380 \mathrm{~cm}$, which would allow for the hanging of the Bear Hunt, with the "salet" (salon) at the back of the house as a possible location.

${ }^{44}$ Cf. Westrheene, Potter, 130-135; and Buvelot, "A Newly Discovered Letter," 93. Both authors refer to a donation by Dirck Jansz van Reenen and Ariaentgen van Balckeneijnde of the complete furnishings in their house on Nieuwe Molstraat to their son Nicolaes, including "all paintings, big and small" (ONA The Hague, 863-3, not paginated, July 5 [not 7, as Westrheene gives it], 1687, notary Pieter van den Beets). The deed does not say, as Westrheene has it, that these belongings were never to be sold; it states that the donation is irrevocable. See also the family archive Storm de Grave, private collection, the Netherlands, inv. no. 823, file on the house on Paviljoensgracht, with documents from 1619 to 1782.

${ }^{45}$ Johannes Immerzeel, De levens en werken der Hollandsche en Vlaamsche kunstschilders, beeldhouwers, graveurs en bouwmeesters van het begin der vijftiende eeuw tot heden (Amsterdam: gebroeders Diederichs, 1842), 1:326, relates that people have assured him that the Bull was painted for Potter's landlord; this in correction of Roeland van Eijnden and Adriaan van der Willigen, Geschiedenis der vaderlandsche schilderkunst (Haarlem: A. Loosjes, 1817), 1:413-14, who suggest that a painting of a fat cow was made for his landlord, a butcher. Nothing has come up since to support Immerzeel's claim; further, we do not know where exactly Potter lived or who his landlord was in 1647.

${ }^{46}$ Deed of sale of a house from the estate of Claes Dircksz Balckeneijnde, The Hague, February 9, 1667, notary Pieter van Roon, ONA The Hague, 581, 10-11, Municipal Archive, The Hague, with reference to the division of his possessions on February 8, 1667, before Aelbert Nierop as commissioner and Willem van Alphen as secretary in the Hof van Holland; legal transfer of the properties of the late Claes Dircksz Balckeneijnde to his heirs, The Hague, June 17, 1667, Oud-Rechterlijk archief The Hague, 384, fol. 434r-435v, with reference to a "verbael" before Nierop and Van Alphen on June 13, 1667. Neither original "verbaelen" could be found in Verbalen 1667-68, Archive of the Hof van Holland, 1351, National Archive, The Hague.

${ }^{47}$ On the wealth of Barbara's father, Adriaen Schas, and his descendants, see Kees Zandvliet, De rijksten van de Republiek. Rijkdom, geloof, macht en cultuur (Zutphen: Walburg Pers, 2018), 247. The Schas and Nierop families were extremely litigant with each other in the handling of their estates, resulting in dozens of documents in the notarial archive and the archive of the Hof van Holland in The Hague, but, alas, without full inventories of their belongings. See, for example, the agreement among the heirs of Cornelia Nierop on the division of her estate, ONA The Hague, 202, 74-75, June 30, 1677, notary Focco Schouten, Municipal Archive, The Hague, and the final account of the possessions of Cornelia Nierop, October 3, 1680, Archive Hof van Holland, no. 3404 (1), National Archive, The Hague. There is no mention of Potter, or the Bull, in any of these documents, nor is there any indication whatsoever that Potter's Bull had ever been part of the decoration of the estate of Santhorst, which belonged to the Schas/Fabricius family since 1672 (see notes 28 and 29).

${ }^{48}$ Frans Grijzenhout, Pro memorie: Een Gouden Eeuw als erfenis (Nijmegen: Vantilt 2011).

${ }^{49}$ Felicity Heal, The Power of Gifts: Gift-Exchange in Early Modern England (Oxford: Oxford University Press, 2014), 87-89, 134-141; Ilana Krausman Ben-Amos, The Culture of Giving: Informal Support and Gift-Exchange in Early Modern England (Cambridge: Cambridge University 
Press, 2008), 165-69 and 205-14. For the Netherlands, the foundational publication is Luuc Kooijmans, Vriendschap en de kunst van het overleven in de zeventiende en achttiende eeuw (Amsterdam: Bert Bakker, 1997). On political clientelism and gift giving in the context of the Frisian stadholderate, see Luuc Kooijmans, Liefde in opdracht: Het hofleven van Willem Frederik van Nassau (Amsterdam: Bert Bakker, 2000), 191-193; and Geert H. Janssen, Princely Power in the Dutch Republic: Patronage and William Frederick of Nassau (1613-64) (Manchester: Manchester University Press, 2008), 175-77. For more in general on the system of patronage under the eighteenth-century stadholders, see Adrianus Johannes Cornelis Maria Gabriëls, De heren als dienaren en de dienaar als heer: Het stadhouderlijk stelsel in de tweede helft van de achttiende eeuw (The Hague: Stichting Hollandse Historische Reeks, 1990), 117-19, 177-81.

Recommended Citation:

Frans Grijzenhout, "Potter's Bull: An Heirloom and a Gift," Journal of Historians of Netherlandish Art 13:1 (Winter 2021). D0l: 10.5092/jhna.2021.13.1.2 